\title{
METODE BERPIKIR KRITIS DALAM PENGAMBILAN KEPUTUSAN \\ YANG TEPAT SECARA KLINIS UNTUK PROFESSIONALISME \\ PERAWAT
}

\author{
Friderikus Zebua \\ zebuafriderikus@gmail.com
}

\section{LATAR BELAKANG}

Perawat merupakan salah satu komponen vital dalam dunia kesehatan karena perawat yang pertama kali menjalin kontak dengan klien dan yang terlama bersama klien terkhusus untuk klien yang harus dirawat inap dan klien yang harus selalu dipantau. Perawat juga disebut sebagai profesi kesehatan yang terpenting dirumah sakit selain karna jumlahnya yang lebih dominan, Sehingga setiap upaya untuk meningkatkan kualitas pelayanan rumah sakit harus juga disertai upaya untuk meningkatkan kualitas pelayanan keperawatan .

Pelayanan keperawatan yang bermutu dan professional andmerupakan harapan semua orang sehingga rumah sakit sebagai penyedia layanan keperawatan dituntut untuk selalu meningkatkan mutu pelayanannya. Ada tiga area tanggung jawab mutu dalam pelayanan keperawatan yang harus menjadi perhatian utama pada setiap organisasi keperawatan yaitu pasien, praktisi, dan profit/ pembiayaan. Untuk area pasien, mutu digambarkan dengan asuhan keperawatan, praktisi digambarkan dengan penampilan kinerja perawat, serta profit digambarkan dengan pembiayaan keperawatan

Dengan demikian perawat harus memberikan pelayanan yang bermutu kepada pasien. Perawat memberikan pelayanan keperawatan kepada semua pasien, baik pasien rawat inap maupun rawat jalan. Perawat sebagai salah satu dari anggota tim kesehatan juga dituntut untuk selalu memberikan pelayanan yang baik kepada pasien. Sehingga perawat harus selalu mengembangkan sikap, perilaku dan pengetahuannya. Sikap dan perilaku yang harus dikembangkan oleh perawat salah satunya yaitu perilaku caring. Mayeroff dalam Morrison \& Burnard (2009/1997) Menggambarkan bahwa caring sebagai suatu proses yang memberikan 
kesempatan pada seseorang untuk pertumbuhan pribadi. Asuhan keperawatan bermutu dapat meningkatkan kemampuan berfikir kritis perawat dalam melakukan pelayanannya.

Pelayanan keperawatan didasarkan dengan pendekatan pengambilan keputusan yang ditingkatkan dengan berfikir kritis (Ignatavicus \& Workman, 2006). Berfikir kritis menurut Sullivan E.J Decker P.J (2001) adalah suatu proses untuk memeriksa berdasarkan pada asumsi, iterpretasi, evaluasi argumentasi, imanjinasi dan eksplorasi alternatif serta mengembangkan refleksi yang kritis untuk mendapatkan kesimpulan sebagai suatu alasan dan justifikasi. Berfikir krtis keperawatan merupakan perpaduan antara pengetahuan, perilaku dan ketrampilan yang dimiliki perawat dalam menganalisa keadaan.

\section{METODE}

Metode yang digunakan pada kajian ini adalah metode kualitatif yang memberikan penjelasan dengan menggunakan analisis pada referensi-refensi yang berupa jurnal dan artikel yang sudah di publikasikan. Artikel ataupun jurnal yang digunakan pada literature ini adalah artikel atau jurnal yang didapatkam dari google scholar, google, library usu pada 10 tahun terakhir penerbitan. Dalam mencari literature reviewnya, menggunakan kata kunci berpikir kritis, pengambilan keputusan keperawatan dan perawat.

\section{HASIL}

Hasil dari kajian ini adalah berfikir kritis akan membantu perawat dalam memecahkan masalah dan mengambil keputusan dengan baik. Dalam praktek sehari-hari perawat harus membuat keputusan diagnostik yang terkait dengan tugasnya dalam melakukan asuhan keperawatan. Perawat selain memberi asuhan keperawatan juga sering kali dituntut untuk dapat membantu dalam pemecahan masalah yang dihadapi oleh klien. Oleh karena itu perawat memerlukan pemikiran kritis, ketrampilan interpersonal dan berlandaskan etika keperawatan sehingga pasien dapat terbantu dalam mengambil keputusan.

Berdasarkan hasil penelitian dari literature review yang meliputi jurnal, teks book, dan ebook, didapatkan metode penelitian yang dapat meningkatkan kemapuan berpikir kritis seorang perawat dalam mengambil sebuah keputusan.Pada literature review tersebut didapatkan hasil bahwa untuk meningkatkan cara berpikir kritis pada perawat yang Professional dilakukan 
dengan menganalisis, mengkaji, mengeksplorasi berbagai bentuk bacaan demi meningkatnya sikap berpikir kritis. Hal ini bertujuan agar sewaktu mengambil sebuah keputusan, perawat tidak salah agar nantinya kulitas dan kuantitas pelayanan yang diberikan kepada pasien sangat baik dan tidak mengecewakan pasien maupun keluarga. Sebelum mengambil keputusan perawat harusnya mengumpulkan data sebanyak-banyaknya dengan mengasah pemikiran mereka agar hasil yang didapat akurat. Seorangnperawat yang memiliki kemampuan berpikir kritis yang baik akan menunjukkan sikap keberanian, intelektual, berpikir tebuka, berpikir analisis, fleksibel, percaya diri, rasa ingin tau dan pemikiran mendalam serta mudah mengambil keputusan sesuai dengan prosedur yang ada dimana dimulai dari pengkajian sampai dengan evaluasi keperawatan.

\section{PEMBAHASAN}

Berpikir kritis merupakan seni gambaran sikap seseorang dalam menganalisis, mengevaluasi sesuatu yang ia lihat, mengklarifikasi yang di dengar, metode pengetahuan untuk berfikir logis dan berargumen serta aplikasi dari ilmu yang dipahami untuk membuat suatu keputusan dan memutuskan sesuatu setelah hal tersebut ia yakini, (Glaser dalam Alec Fisher, 2001;OU,2008). Berpikir kritis sangat dibutuhkan oleh siapa saja yang menyandang profesi sebagai nurse atau pun perawat. Berpikir kritis sangat dibutuhkan dan sudah sepantasnya mahasiswa keperawatan dibekali hal tersebut karena sangat berkaitan dan bersinggungan dengan pengambilan keputusan.

Kepandaian berpikir kritis dalam dunia keperawatan sangatlah dibutuhkan, karena untuk pemecahan suatu masalah (problem solving) bagi seorang perawat sangat berkaitan erat terkait keputusan dan tindakan yang akan ia ambil, melalui sudut padang serta latar belakang yang berbeda. Melalui berpikir kritis perawat diasah untuk meningkatkan kemampuan verbal dan analitik meningkatkan kemampuan verbal dan analitik yang sistematis sehingga mengeksplorasikan gagasan - gagasan, menganalisis masalah hingga memahami masalah khususnya dalam bidang keperawatan. Berpikir kritis meningkatkan kreatifitas. Untuk menghasilkan solusi kreatif terhadap suatu masalah tidak hanya memerlukan gagasan baru namun dengan berpikir kritis dapat mengevaluasi gagasan lama dan baru, memilih yang terbaik dan memodifikasi bila perlu. Perawat sebagai praktisi maupun dalam pendidikan harus menggunakan unsur-unsur dasar dalam berpikir kritis agar asuhan keperawatan yang akan diberikanberkualitas. 
Berpikir Kritis dalam Pengambilan Keputusan Kemampuan berpikir kritis dapat ditingkatkan dengan motivasi yang positif dari lingkungan tempat perawat bekerja. Suatu kreativitas penting untuk membangkitkan motivasi secara individu, sehinnga seorang peraeat mampu mengembangkan konsep baru dengan pendekatan inovatif dalam memecahkan masalah agar keputusan yang diambil akurat dan jelas. Perawat juga harus terbuka dalam menerima kritik karena akan mengakibatkan hal yang positif.

Proses Pengambilan Keputusan Proses pengambilan keputusan adalah salah satu penyelesaian yang dinamis. Penyebab umum gagalnya pengambilan keputusan adalah kurang tepat dalam mengidentifikasi masalah. Oleh karena itu, identifikasi masalah merupakah langkah yang paling penting karena kualitas hasil tergantung pada keakuratan hasil dalam mengidentifikasi masalah.

Berdasarkan hasil literature review didapatkan metode pembelajaran yang mempengaruhi kemampuan berpikir kritis dan kepercayaan mahasiswa keperawatan yaitu simulasi, konferensi klinis, ronde keperawatan, emonstrasi model, dan peta konsep Peta konsep adalah salah satu contoh yang diusulkan untuk peningkatan pemikiran kritis, dengan metode ini mahasiswa dapat menggambarkan mapping konten yang mereka pelajari, oleh karena itu mahasiswa dapat menggunakan keterampilan kognitif mereka dari analisis, evaluasi, dan penalaran. Selain itu, mereka akan dapat merangkum konten dan mengingatnya dengan baik (Wheeler \& Collins, 2003). Ronde keperawatan mirip dengan studi kasus, memberikan kesempatan untuk mengeksplorasi masalah pasien dan beragam tindakan, menganalisis perawatan dan mengusulkan intervensi baru, dan mendapatkan wawasan tentang situasi klinis yang berbeda (Gaberson \& Oermann, 2010), selain itu di dalam ronde keperawatan juga menggunakan problem based learning untuk mengetahui dan mendiskusikan terkait kasus pasien. Sementara itu, untuk metode konferensi klinis, metode teresebut dapat menjadi metode yang inovatif dan efektif untuk meningkatkan pemikiran kritis mahasiswa keperawatan, pemecahan masalah, penalaran dan penilaian klinis, serta mengintegrasikan teori ke dalam praktik. Selain itu, komponen penting dari pelaksanaan konferensi klinis adalah memastikan instruktur klinis terus mengevaluasi strategi yang digunakan untuk memenuhi kebutuhan dalam pengalaman klinis mahasiswa (Scronce, 2013). 
Pengambilan keputusan adalah suatubpendekatan yang sistematis terhadap hakekat suatu masalah dengan mengumpulkan fakta-fakta dan data, menemukan alternative yang matang untuk mengambil suatu tindakan yang tepat.

Ada lima hal yang perlu diperhatikan dalam pengambilan keputusan, yaitu :

1) Dalam proses pengambilan keputusan tidak terjadi secara kebetulan;

2) Masalah harus diketahui dengan jelas;

3) Pengambilan keputusan tidak dilakukan secara sembrono;

4) Pemecahan masalah harus didasarkan pada fakta-fakta yang telah.terkumpul secara sistematis;

5).Keputusan yang baik adalah keputusan yang telah dianalisa secara matang. Apabila pengambilan keputusan tidak didasarkan pada kelima hal diatas, akan menimbulkan berbagai masalah, diantaranya :

- Tidak tepatnya keputusan;

- Tidak terlaksananya keputusan karena tidak sesuai dengan kemampuan organisasi baik dari segi manusia, uang maupun material;

- Ketidakmampuan pelaksana untuk bekerja karena tidak ada sinkronisasi antara kepentingan organisasi dengan orang-orang di dalam organisasi tersebut;

- Timbulnya penolakan terhadap keputusan.

Dalam penerapan pembelajaran pemikiran kritis di keperawatan, dapat digunakan tiga model, yaitu: feeling, vision model, dan examine model yaitu sebagai berikut:

1. Feling model, Model ini menerapkan pada rasa, kesan, dan data atau fakta yang ditemukan. Pemikir kritis mencoba mengedepankan perasaan dalam melakukan pengamatan, kepekaan dalam melakukan aktifitas keperawatan dan perhatian.Misalnya terhadap aktifitas dalam pemeriksaan tanda vital, perawat merasakan gejala, petunjuk dan perhatian kepada pernyataan serta pikiran klien. 
2. Vision model, Model ini dingunakan untuk membangkitkan pola pikir, mengorganisasi dan menerjemahkan perasaan untuk merumuskan hipotesis, analisis, dugaan dan ide tentang permasalahan perawatan kesehatan klien, beberapa kritis ini digunakan untuk mencari prinsipprinsip pengertian dan peran sebagai pedoman yang tepat untuk merespon ekspresi.

3. Exsamine model, Model ini dungunakan untuk merefleksi ide, pengertian dan visi. Perawat menguji ide dengan bantuan kriteria yang relevan. Model ini digunakan untuk mencari peran yang tepat untuk analisis, mencari, meguji, melihat konfirmasi, kolaborasi, menjelaskan dan menentukan sesuatu yang berkaitan dengan ide.

Pengambilan keputusan dalam keperawatan merupakan adalah hal yang sangat penting karena akan memengaruhi asuhan keperawatan yang karena diberikan. Pengambilan keputusan ini sendiri mencakup semua penilian dari segala aspek dan kegiatan yang diperlukan guna untuk mencari pilihan keputusan yang terbaik. Sesuai model pengambilan keputusan terdapat dua proses pengambilan keputusan yaitu proses rutin dalam pengambilan keputusan terprogram dan proses kreatif dalam pengambilan keputusan tak terprogram.

- Proses rutin (Keputusan terprogram)
1) Identifikasi Masalah
2) Pemilihan Alternatif
3) Alternatif piluhan
4) Implementasi keputusan
5) Evaluasi

- Proses kreatif (Keputusan tak terprogram)

1) Merasa adanya kebutuhan

2) Persiapan

3) Pematangan pemikiran

4) Penjelasan

5) Pembuktian

6) Implementasi keputusan

7) Evaluasi 


\section{PENUTUP}

Metode pembelajaran yang dapat berpengaruh terhadap kemampuan berpikir kritis dan kepercayaan diri mahasiswa keperawatan diantaranya adalah konferensi klinis, simulasi, demonstrasi model, peta konsep dan ronde keperawatan, oleh karena itu pembimbing klinik harus mengetahui dengan baik metode pembelajaran yang akan digunakan, agar dapat memilih metode pembelajaran yang tepat dalam pembimbingan khususnya di lingkungan klinik.

Pengambilan keputusan merupakan proses pemecahan masalah yang berfokus pada analisa situasi yang sulit untuk mengambil solusi yang memutuskan permasalah tersebut. Pengambilan keputusan dengan konsep berfikir kritis dalam keperawatan merupakan hal yang kompleks, karena menyangkut permasalahan manusia. Oleh karena itu seorang perawat dituntut untuk dapat memutuskan sesuatu dengan baik dan tidak merugikan orang lain yang berlandaskan etika profesi keperawatan. Dalam pengambilan keputusan perawat harus mempertimbangkan segala aspek, baik dari pasien itu sendiri, keluarga pasien, tenaga kesehatan lain, dan psiko, sosial, dan cultural yang diterapkan, Perawat juga harus ikut membantu klien ataupun keluarga klien dalam mengambil keputusan yang berhubungan dengan kesehatan klien. Oleh sebab itu sangat penting untuk perawat dalam belajar dan memahami bagaimana mengambil keputusan yang tepat dan tidak melanggar etika profesi keperawatan diikuti konsep berfikir kritis yang sudah dimiliki perawat itu sendiri.

\section{DAFTAR PUSTAKA}

Ayu N., Jurnal Kesehatan Holistik.(2018). Vol 12, No. 1DS, Bambang Sudono., A, Dhani Setya.H, Rif Atiningtyas. (2017).Gambaran Kemampuan Berpikir Kritis Perawat Primer dalam Pelaksanaan Asuhan Keperawatan di Rumah Sakit Islam Surakarta. Jurnal Ilmu Keperawatan Indonesia, 10(1), 79-106.

Alfianur. Susanti. Padilah, R,.Purnamasari, A. (2018). Gambaran pengambilan keputusan klinis dalam P4K (Program perencanaan persalinan dan pencegahan komplikasi) di daerah pesisir pantai amal lama tarakan. The Journal of Borneo Holistic Health, 1, 160-169.

Baumgarder, D.J. (2018). Uncertainly and competing priorities in shared clinical decisionmaking. Journal of PatientCentered Research and Riviews, 5, 137-139. 
Deniati, K,. Anugrahwati, R,. \& Suminarti,T. (2018). Pengaruh berpikir kritis terhadap kemampuan perawat pelaksana dalam melakukan asuhan keperawatan di rumah sakit hermina bekasi tahun 2016. The Journal of Holistic Healthcare, 12,21-25.

Hastuti, W, \& Widiyaningsih. (2017). Aplikasi consept mapping dalam pemberian asuhan keperawatan di state maternitas. Jurnal Keperawatan dan Pemikiran Ilmiah, 3, 19-16.

Heni. (2017). Berfikir Kritis Dalam Proses Keperawatan. Jurnal Keperawatan, 3(1), 26-29

Indriate. (2013). Berfikir Kriris dalam Proses Keperawatan. Jurnal Keperawatan, 6(2), 89-93.

Kowiyah. (2012). Kemampuan Berpikir Kritis. Jurnal Pendidikan Dasar, 3(5), 175-179.

Mc Cabe, D. E., Gilmartin, M. J., \& Goldsamt, L. A. (2016). Student Self-confidence with Clinical Nursing Competencies in A High-dose Simulation Clinical Teaching Model. Journal of Nursing Education and Practice, 6(8), 52-58.

Moattari, M., Soleimani, S., \& Mehbodi, F. (2014). Clinical concept mapping : Does it improve discipline-based critical thinking of nursing students ? Iranian Journal of Nursing and Midwifery Research, 19(1), 70-76

Patmawat, T.A,. Saleh, A,. Syahrul, S.(2018).Efektifitas Metode Pembelajaran Klinik terhadap kemampuan berpikir kritis dan kepercayaan diri. Jurnal Keperawatan Muhammadiyah, 3, $88-94$.

Simamora, R. H. (2019). Menjadi perawat yang: CIH'HUY. Surakarta: Kekata Publisher.

Simamora, R. H. (2005). Hubungan Persepsi Perawat Pelaksana Terhadap Penerapan Fungsi Pengorganisasian Yang Dilakukan Oleh Kepala Ruangan Dengan Kinerjanya Diruang Rawat Inap RSUD Koja Jakarta Utara (Doctoral dissertation, Tesis FIK UI, Tidak dipublikasikan).

Surtiyanti, Y., \& Mulyadi. (2019).Analisis Faktor-Faktor yang Mempengaruhi Penerapan Berpikir Kritis Perawat dalam Melaksanakan Asuhan Keperawatan di Rumah Sakit.Jurnal Keperawatan Raflesia,1(1), 21-32 